\title{
The use of ultrasound and slightly acidic electrolyzed water as alternative technologies in the meat industry
}

\author{
${ }^{1 *}$ Flores, D. R. M., ${ }^{1}$ Athayde, D.R., ${ }^{1}$ Silva, M.S., ${ }^{1}$ Silva, J.S., ${ }^{1}$ Genro, A.L.G., ${ }^{2}$ Cichoski, \\ A.J., ${ }^{2}$ Barin, J.S., ${ }^{2}$ Wagner, R., ${ }^{2}$ Terra, N.N. and ${ }^{2}$ Menezes, C.R. \\ ${ }^{1}$ Posgraduate Program in Food Science and Technology (PPGCTA), Federal University of Santa Maria \\ (UFSM), Avenida Roraima, 1000, Santa Maria, RS, Brasil \\ ${ }^{2}$ Departament of Food Science and Technology (DTCA), Federal University of Santa Maria (UFSM), \\ Avenida Roraima, 1000, Santa Maria, RS, Brasil
}

\begin{abstract}
Article history:
Received: 25 May 2017

Received in revised form: 12 June 2017

Accepted: 14 June 2017

Available Online: 21 June 2017
\end{abstract}

\section{Keywords:}

Meat quality,

Ultrasound,

Electrolyzed water,

Bacteria,

Environment

\section{DOI:}

http://doi.org/10.26656/

fr.2017.5.059

\begin{abstract}
The quality of meat from different animal species is defined by chemical, physical sensory and microbiological characteristics, which can be influenced by procedures during the slaughter of animals. Technologies such as ultrasound (US) and slightly acidic electrolyzed water (SAEW) are being studied in order to assist in food processing and in developing methods that are economically viable and environmentally sustainable. The aim of this paper is to discuss the relationship between US and SAEW in relation to tenderness, microbiology, and oxidation of meat. The meat industry was a pioneer in the use of the ultrasound, which initially aimed to determine the layer of fat on carcasses and subsequently improve the tenderness of the meat. Recently studies mention that the ultrasound and SAEW can influence the microbiological parameters. The combination of both technologies should also be considered, with the possibility of enhancing the antimicrobial effects. However, there is little information regarding oxidative parameters promoted in meat for these two alternative technologies, where the individual or when interspersed use. Knowing the actions and consequences of ultrasound and SAEW in meat will enable the opening of new perspectives about the application of these technologies in the meat industry.
\end{abstract}

\section{Introduction}

The meat quality of different species of slaughtered animals can be characterized by parameters such as appearance, texture, taste, color, and aroma (Vieira, 1999). Historically, the equipment's modernization and industrial's installations made possible that the meat industry offers a meat with quality and with a satisfactory microbiological safety to the market (Gomide et al., 2009). Technological innovations developed for the agro-industrial sector are optimized to enhance value and preserve the quality of food, to protect the environment and to allow the conquest of markets internationally (Santini and Filho, 2003; Sereia et al., 2015).

Alternative technologies, such as slightly acidic electrolyzed water (SAEW) and ultrasound (US), are simple ways of optimizing the use of natural resources, providing economy investment (Clark, 2011) and assisting the preservation of foods (Chemat et al., 2011). The application of US can benefit the meat by modifying the tenderness of it (Jayasorryia et al., 2004). When combined with high temperatures, its effect against the bacteria development tends to increase (Pagan et al., 1999). Applications of SAEW have shown opposite effect against the bacteria in various temperature ranges and application modes (Northcutt et al., 2007; Koide et al., 2009). However, the SAEW and US still require greater understanding to enhance its applications and, consequently, be used in the meat industry. Therefore, in this review, will be discussed the principles of these alternative technologies in contact with the tenderness, microbiology and the meat oxidation.

\section{Ultrasound}


In the perspective of food technology, US is a sound wave with a high frequency vibration, which promotes a mix of fluids and the shear force (Kentish and Feng, 2014). The sound spectrum can be divided into regions, which are low frequency and high intensity (20-100 $\mathrm{kHz})$ and high frequency and low intensity (1-10 MHz) (Patil et al., 2013).

The ultrasound effects are originated from cavitation (Shchukin et al., 2011), which can be considered as small implosions that provide detachment of energy levels. In local operations, the gaseous and liquid phases reach temperatures of about $2000-5000^{\circ} \mathrm{C}$ and pressures above $1000 \mathrm{~atm}$ (Suslick et al., 1986). Cavitation mainly occurs at low frequencies and its energy increases with the rise of the wave's intensity (Got et al., 1999).

\subsection{Ultrasound and meat tenderization}

In order to add value to the meat and make it tender, techniques are routinely used in cutting with less degree of tenderness and less profitable portions in carcasses with a high-grade finishing (Kinsman et al., 1994; Bekhit et al., 2014). Traditional methods are used by the meat processing industry to improve the meat tenderness, including mechanical, enzymatic and chemical forms (Mane and Dhanze, 2014). In laboratory and pilot scale, various US applications have been proposed in the meat processing and beneficiation, such as in the meat tenderization (Zhou et al., 2015). The US can act in muscle tissue promoting changes in physical structures and protein and enzymatic metabolism, improving the meat tenderness (Jayasooryia et al., 2004). As well as in the changes of proteolysis and water retention capacity (Dolatowski et al., 2007) and in the action of the enzyme involved in the meat maturation (Got et al., 1999).

Chang and Wong (2012) exposed fish filet to US of $60 \mathrm{kHz}, 4 \mathrm{~W} / \mathrm{cm}^{2}$ of intensity and observed that the firmness of the sonicated files obtained values of 8 to 9 $\mathrm{N}$, compared to 14 to $15 \mathrm{~N}$ of the non-sonicated groups. The authors suggested which ultrasound promoted the acceleration of protein and enzymatic metabolism of the fish filet. Xiong et al. (2012) applied $25 \mathrm{kHz}$ US, $12 \mathrm{~W} /$ $\mathrm{cm}^{2}$ intensity for 4 minutes in chicken breast and observed reduction by $1.19 \mathrm{~kg}$ of shear force compared to non-sonicated groups. This reduction is related to an increase in the proteolytic enzyme activities after the ultrasound application, such as caspase-3, which favored muscle degradation, tenderness and water retention of the poultry meat.

\subsection{Ultrasound and microbiological contamination of meat}

Because of the microbiological contamination risk of the meat during the steps in the process, the slaughterhouses use chlorinated water (Kotula et al., 1974; Tozzeti et al., 2009; Kameyama et al., 2012) to assist in the carcasses decontamination and the cooling to extend the meat shelf life (Cunningham and Lawrence, 1977; Jay, 2005). Considering the high consumption of water in the slaughterhouses, Krieger (2007) suggested a volume reduction of 50\% through the implementation of more effective technologies in sanitizing and cleaning processes. Due to the practicality of application, antimicrobial activity, and environmental sustainability, the ultrasound is the target of research and development on a reduced scale in the agro-industrial segment (Chemat et al., 2011).

The most probable mechanism of microorganism inactivation by the US would be the direct effects of cavitation and the production of reactive species of oxygen would be the indirect effects. In sonication of aqueous solutions, occur the formation of hydroxyl radicals $(\cdot \mathrm{OH})$, hydroperoxide $(\cdot \mathrm{OOH})$ and extremely reactive species of hydrogen $(\cdot \mathrm{H})$ (Suslick, 1989; Mason and Lorimer, 2002), which can recombine to the form of peroxide hydrogen $\left(\mathrm{H}_{2} \mathrm{O}_{2}\right)$ (Hua and Thompson, 2000). According to Hua and Thompson (2000), these oxidizing species can diffuse and strike organic structures, functioning as sanitizers.

The low frequency and high intensity of US reduced by1 to $2 \log \mathrm{CFU} / \mathrm{cm}^{2}$ enterobacteria, such as Salmonella enterica serovar Derby and Infantis, Yersinia enterocolitica and Escherichia coli, which are present on the surface of carcasses and meat pork when they were combined by pressure for 4 to 10 seconds (Morild et al., 2011). A number of mesophilic aerobic and lactic acid bacteria present in meat pork, decreased 40 to $50 \%$ after 2 minutes with the $25 \mathrm{kHz}$ US and $2 \mathrm{~W} / \mathrm{cm}^{2}$ intensity (Dolatawski and Stasiak, 2002). As was also observed reduction by $3 \log \mathrm{CFU} / \mathrm{cm}^{2}$ enterobacteria, mesophilic aerobic and psychrotrophic bacteria in beef exposed with $40 \mathrm{kHz}$ US and $11 \mathrm{~W} / \mathrm{cm}^{2}$ intensity for between 60 90 minutes (Caraveo et al., 2014).

The antimicrobial action of the US is favored in temperatures between $60^{\circ} \mathrm{C}$ and $70^{\circ} \mathrm{C}$ (Raso et al., 1998; Pagan et al., 1999; Cichoski et al., 2015), because these temperatures make the microorganism's cell structure more susceptible to the physical actions, favoring the sonication effects. Even that, the antimicrobial effect of 
the US is more efficient at higher temperatures, Alliger (1975); Guerrero et al. (2001) and Herceg et al. (2012) reported that in temperatures between $10^{\circ} \mathrm{C}$ and $20^{\circ} \mathrm{C}$, the environmental conditions make the cavitation potential more intense, which further favor the formation of reactive oxygen species (ROS) and shear strength.

\section{Electrolyzed water}

In order to be generated in a traditional manner, the chlorinated water needs to pass through the manipulation of large volume of highly volatile chemicals, which are irritants to the respiratory tract and harmful to human health (Brazil, 2004). However, the use of new technologies for the generation of chlorinated water, such as electrolysis, can make this process more practical, simple and environmentally appropriate (Rahman et al., 2016). Due to its minimal corrosive potential, SAEW may be less aggressive to human health and the environment, requiring minimum safety processes to manipulate it (Zacharia et al., 2010). The operational costs associated with the application of SAEW can also be lesser because of the possibility of local production (Al-Haq et al., 2005).

The operation's principle of the electrolyzed water equipment consists of the passage of a saline solution $(\mathrm{NaCl}$ or $\mathrm{KCl})$ in pure water through an electrolysis cell, which is composed of two poles: positive (anode) and negative (cathode) (Zoulias et al., 2013). The saline solution generates an electric current between the poles, and the changes in its concentration may generate different chlorine values available. With variations from 2 to $20 \mathrm{~g} / \mathrm{L}$ of $\mathrm{NaCl}$ in pure water, it is possible to produce electrolyzed water with chlorine concentrations from 5 to $200 \mathrm{mg} / \mathrm{L}$ (Hsu, 2005; Rahman et al., 2016). The mixture of acidic electrolyzed water and basic electrolyzed water forms the SAEW, which has a $\mathrm{pH}$ between 6 and 6.5, oxidation-reduction potential (Eh) $800-900 \mathrm{mV}$, containing predominantly $\mathrm{HOCl}(95 \%)$ and hypochlorite ions $\left(\mathrm{ClO}^{-}-5 \%\right)$ and traces of $\mathrm{Cl}_{2}$ (Guentzel et al., 2008).

\subsection{Slightly acidic electrolyzed water and} microbiological contamination of meat

The SAEW includes mechanisms that promote the reduction of microbial growth and the inactivation of microorganisms. These mechanisms occur through oxidation of protein compounds involved in cellular metabolism, cellular rearrangements, induction of DNA damage (Huang et al., 2008), apoptosis and redox reactions involving electron transfer and formation of disulfide bridges (Liao et al., 2006).

The SAEW has aroused great interest in agriculture, medicine and the food industry for its versatility, showing the antimicrobial activity even when it is applied in different ways. Studies have demonstrated with SAEW in chlorine concentrations between 5 and $120 \mathrm{mg} / \mathrm{L}$, were effective to reduce by 5 to $6 \log \mathrm{CFU} /$ $\mathrm{cm}^{2}$ Escherichia coli, Listeria monocytogenes, Staphylococcus aureus and Salmonella enterica serovar Enteritidis in fresh meat of chicken, beef and pork (Ayebah and Hung, 2005; Northcutt et al., 2007; Koide et al., 2009; Zhang et al., 2011; Shimamura et al., 2015). In addition, it was effective in the cleaning and disinfection of knives and food processing equipment (Fabrizio and Cutter, 2005; Huang et al., 2008; Cao et al., 2009; Cichoski et al., 2015).

Most of the SAEW applications in food was performed at temperatures between $20^{\circ} \mathrm{C}$ to $40^{\circ} \mathrm{C}$ (Kim et al., 2005; Ding et al., 2015; Shiroodi et al., 2016). However, Cao et al. (2009) and Rahman et al. (2013) observed that SAEW retained its antimicrobial activity even when it is applied at temperatures between $5^{\circ} \mathrm{C}$ and $10^{\circ} \mathrm{C}$ because it reduced $3 \log \mathrm{CFU} / \mathrm{cm}^{2}$ Listeria spp., Escherichia coli, and Salmonella spp., inoculated on the surface of eggs and pork.

The SAEW combined with other alternative technologies can potentiate its antimicrobial effects, further assisting in reducing the number of microorganisms (Liu et al., 2013). Recently, the combination of US and SAEW technologies has been described with satisfactory results. In the same way, Forghani and Oh (2013) and Ding et al. (2015) which associated US of $40 \mathrm{kHz}$ with SAEW $\left(25-30 \mathrm{mg} / \mathrm{L} \mathrm{Cl}_{2}\right.$ at $25^{\circ} \mathrm{C}$ ) observed an increase of $20 \%$ to $30 \%$ reduction of the number of microorganisms, as compared to isolated application of technology. It shows that synergism occurred between technologies because the cavitation effects facilitated the penetration of chlorinated compounds of SAEW in the microorganisms' cellular structure.

\section{Ultrasound and slightly acidic electrolyzed water effects in meat oxidation}

There is little information on the effects of US and SAEW lipid and protein oxidation, restricting the studies of specific species of meat. This information becomes important because the sonication of water can generate ROS, pressures and high temperatures (Marchioni et al., 2009) and SAEW can also cause damage to biological 
structures, including the muscle tissues (Shirahata et al., 1997).

Fish filets, which were exposed for more than 30 minutes in US of $60 \mathrm{kHz}$ and $4 \mathrm{~W} / \mathrm{mL}$ of intensity, present strongly indicative of increased muscle metabolism and proteolysis during the storage period, which contributed to increase by 0.01 to $0.2 \mathrm{mg} / \mathrm{MDA} / \mathrm{kg}$ the value of thiobarbituric acid reactive substances (TBARS) (Chang and Wong, 2012). Turienzo et al. (2012) demonstrated that the application of $35 \mathrm{kHz}$ US to fresh salmon for between 15 and 20 minutes, showed low values of lipid oxidation $(6 \mathrm{meq} / \mathrm{kg}$ peroxides and $1.25 \mathrm{mg} / \mathrm{MDA} / \mathrm{kg}$ TBARS). In non-sonicated fresh salmon, showed $9 \mathrm{meq} / \mathrm{kg}$ peroxides and $6.5 \mathrm{mg} / \mathrm{MDA} /$ $\mathrm{kg}$ TBARS. These values of low lipid oxidationwere correlated to the changes occurred in the fish filets protein structure and, consequently, it protected that compounds would suffer deterioration.

Apparently, the SAEW application in fish and pork showed reduction and no interference in the formation of oxidized lipid compounds. Rahman et al. (2013) reported that pork immersed for 10 minutes in SAEW at $25^{\circ} \mathrm{C}$ with $\mathrm{pH} 6.8$, Eh of $700 \mathrm{mV}$ and chlorine concentration of $10 \mathrm{mg} / \mathrm{L}$ showed no changes in the formation of TBARS compared to control treatments with distilled water. Mahmoud et al. (2006) reported that the immersion of carp filets in basic electrolyzed water $(\mathrm{pH} \mathrm{11,} \mathrm{Eh}-850$ $\mathrm{mV}$ and $0 \mathrm{mg} / \mathrm{L} \mathrm{Cl}_{2}$ ) at first and then in acidic electrolyzed water ( $\mathrm{pH} \mathrm{2}$, Eh $1137 \mathrm{mV}$ and $40 \mathrm{mg} / \mathrm{L} \mathrm{Cl}_{2}$ ) at $25^{\circ} \mathrm{C}$ for 15 minutes, significantly reduced by 3 to 4 $\mathrm{meq} / \mathrm{kg}$ the amount of peroxides compared to untreated groups. The immersion in basic water could function as an antioxidant, preserving tissues and oxidative damage structures (Shirahata et al., 1997).

Oxidative and functional mechanisms of meat protein are briefly studied following US applications, but they are not described in the SAEW application. Low frequency and high intensity of US can react to decrease the size of particles in bovine protein extracts, fish and bovine serum albumin (Gülseren et al., 2007; Sullivan et al., 2016). Gülseren et al. (2007) also reported that free thiol groups were reduced $30 \%$ after the application of ultrasound in bovine serum albumin extracts, suggesting that ROS produced by sonication can react with albumin and thereby contribute to oxidative changes demonstrated.

\section{Conclusion}

The US can tenderize cuts of meat by direct and indirect effects of cavitation and can ensure the safety to present the effect of microorganism inactivation. The SAEW has great potential for using in the meat industry due to its antimicrobial effects are maintained when it is used in various forms and application temperatures. The antimicrobial action can be potentiated with the reconciliation of SAEW and US by combining the effects of cavitation and chlorine. Both technologies can reduce the consumption of natural resources and chemicals used by agribusinesses and be as effective as traditional methods or more than this. The oxidative effects of ultrasound are not clear, and there is a tendency to induce lipid and protein oxidation. However, the use of SAEW does not induce oxidative alterations, promoting the use of basic water previously the reduction of oxidative changes. Further studies are needed on the application of these technologies in relation to protein and lipid oxidation in the meat of different species to make the development of large-scale applications possible.

\section{References}

Alliger, H. (1975). Ultrasonic disruption. American Laboratory, 10, 75-85.

Al-Haq, M. I., Sugiyama, J. and Isobe, S. (2005). Applications of electrolyzed water in agriculture and food industries. Food Science Technologies Research, 11(2), 135-150. doi:doi.org/10.3136/ fstr.11.135.

Ayebah, B. and Hung, Y.C. (2005). Electrolyzed water and its corrosiveness on various surface materials commonly found in food processing facilities. Journal of Food Process Engineering, 28, 247264.doi: 10.1111/j.1745-4530.2005.00424.x.

Bekhit, AEDA., Carne, A., Ha, M. and Franks, P. (2014). Physical intervention to manipulate texture and tenderness of fresh meat: a review. International Journal of Food Properties, 17(2), 433-453. doi: 10.1080/10942912.2011.642442.

Cao, W., Zhu, Z.W., Shi, Z.X., Wang, C.Y. and Li, B.M. (2009). Efficiency of slightly acidic electrolyzed water for inactivation of Salmonella enteriditis and its contaminated shell eggs. International Journal of Food Microbiology, 130(2), 88-93. doi:10.1016/ j.ijfoodmicro.2008.12.021

Caraveo, O., Alarcon, R.A.D., Renteria, A., Santellano. and E. Paniwnky, L. (2014). Physicochemical and microbiological characteristics of beef treated with high-intesity ultrasound and stored at $4^{\circ} \mathrm{C}$. Journal of Science Food Agricultural, 95(12), 2487-2493. doi: 


\subsection{2/jsfa.6979.}

Cichoski, A.J., Rampelotto, C., Silva, M.S., Moura, H.C., Terra, N.N., Wagner, R. and Menezes, C.R. (2015). Ultrasound-assisted post-packaging pasteurization of sausages. Innovative Food Science and Emerging Technologies, 30, 132-137. doi: 10.1016/j.ifset.2015.04.011

Clark, J. H. (2011). Alternatives to conventional food processing In Introduction to Green Chemistry, p. 18. U.K: RSC Publishing,

Chang, H.C. and Wong, R.X. (2012). Textural and biochemical properties of cobia (Rachycentron canadum) sashimi tenderized with the ultrasonic water bath. Food Chemistry, 132, 1340-1345. Doi: 10.1016/j.foodchem.2011.11.116.

Chemat, F., Huma, Z. and Khan, M.K. (2011). Applications of ultrasound in food technology: processing, preservation, and extraction. Ultrasonic Sonochemistry, 18(4), 813- 835. doi: 10.1016/ j.ultsonch.2010.11.023.

Cunningham, H.M. and Lawrence, G.A. (1977). Effect of exposure of meat and poultry to chlorinated water on the retention of chlorinated compounds and water. Journal of Food Science, 42(6), 1504-1509. doi:10.1111/j.1365-2621.1977.tb08411.x.

Ding, T., Ge, Z., Shi, J., Xu, Y.T., Jones, C.L. and Liu, D.H. (2015). Impact of slightly acidic electrolyzed water (SAEW) and ultrasound on microbial loads and quality of fresh fruits. Food Science and Technology, 60, 1195-1199. doi: 10.1016/ j.lwt.2014.09.012.

Dolatowski, Z. J., Stadnik, J. and Stasiak, D. (2007). Application of ultrasound in food technology. Technologia Alimentaria, 6(3), 89-99. Retrieved from:http://www.food.actapol.net/pub/8_3_2007.pdf.

Dolatowski, Z.J. and Stasiak, D.M. (2002). Bacterial contamination of meat and meat products after ultrasound treatment. Technologia Alimentaria, 1, 55 -65. Retrieved from: http://www.food.actapol.net/ pub/6_1_2002.pdf.

Fabrizio, K.A. and Cutter, C.N. (2005). Application of electrolyzed oxidizing water to reduce Listeria monocytogenes on ready-to-eat meats. Meat Science, 71(2), 327-333. doi: 10.1016/j.meatsci.2005.04.012.

Forghani, F. and Oh, D.H. (2013). Hurdle enhancement of slightly acidic electrolyzed water antimicrobial efficacy on Chinese cabbage, lettuce, sesame leaf and spinach using ultrasonication and water wash. Food Microbiology, 36, 40-45. doi: 00210.1016/ j.fm.2013.04.002.
Guentzel, J. L., Lam, K.L., Callan, M.A., Emmons, S.A. and Dunham, V.L. (2008). Reduction of bacteria on spinach, lettuce and surfaces in food service areas using neutral electrolyzed oxidizing water. Food Microbiology, 25, 36-41. doi: 10.1016/ j.fm.2007.08.003.

Gomide, L.A.M. (Ed.) (2009). Pre Chilling. In Slaughter technology and carcass tipification, p. 233-236. Viçosa, Brazil: UFV

Got, F., Culioli, J., Berge, P., Vignon, X., Astruc, T., Quideau, J.M. and Lethiec, M. (1999). Effects of high-intensity high-frequency ultrasound on ageing rate, ultrastructure and some physico-chemical properties of beef. Meat Science, 51, 35-42. doi: 10.1016/S0309-1740(98)00094-1.

Guerrero, S., Lopez, M.A. and Alzamora, S.M. (2001). Effect of ultrasound on the survival of Saccharomyces cerevisae: influence of temperature, pHand amplitude. Innovative Food Science and Emerging Technologies, 2, 31-39. doi: 10.1016/ S1466-8564(01)00020-0.

Gulseren, I. (2007). Structural and functional changes in ultrasonicated bovine serum albumin solutions. Ultrasonic Sonochemistry, 14, 173-183. doi: 10.1016/j.ultsonch.2005.07.006.

Herceg, Z., Jambrak, A.R., Lelas, V. and Thagard, S.M. (2012). The effect of high intensity ultrasound treatment on the amount of Staphylococcus aureus and Escherichia coli in milk. Food Technology Biotechnology, 50, 46-52.

Hsu, S.Y. (2005). Effects of flow rate, temperature and salt concentration on chemical and physical properties of electrolyzed oxidizing water. Food Engineering, 66, 171-176. doi: 10.1016/ j.jfoodeng.2004.03.003.

Huang, Y. R., Hung, Y.C., Hsu, S.Y., Huang, Y.Y. and Hwang, D.F. (2008). Application of electrolyzed water in the food industry. Food Control, 19, 329345. doi: 10.1016/j.foodcont.2007.08.012.

Hua, I. and Thompson, J. E. (2000). Inactivation of Escherichia coli by sonication at discrete ultrasonic frequencies. Water Research, 34(15), 3888-3893. doi:10.1016/S0043-1354(00)00121-4.

Jay, J. M. (Ed.). (2005). Fresh meat and poultry In Food microbiology. In Food Microbiology, p. 75-99. Porte Alegre: Artmed.

Jayasooriya, S.D., Bhandari, B.R., Torley, P. and D'arcy, B.R. (2004). Effect of high power ultrasound waves on properties of meat: a review. International Journal of Food Properties, 7(2), 301-319. doi: 


\subsection{1/JFP-120030039}

Kameyama, M., Chuma, T., Nishimoto, T., Oniki, H., Yanagitani, Y., Kanetou, R., Gotou, K., Shahada, F., Iwata, H. and Okamoto, K. (2012). Effect of cooled and chlorinated chiller water on Campylobacter and coliform on broiler carcasses during chilling at a middle-size poultry processing plant. Journal Veterinarian Medical Science, 74(1), 129-133. doi: doi.org/10.1292/jvms.11-0167

Kim, C., Hung, Y.C. and Russell, S.M. (2005). Efficacy of electrolyzed water in the prevention and removal of fecal material attachment and its microbicidal effectiveness during simulated industrial poultry processing. Poultry Science, 84, 1778-1784. doi: 10.1093/ps/84.11.1778.

Kinsman, D.M., Kotula, A.W. and Breidensteins, B.C. (1994). Quality characteristics In Muscle food, p. 296-333. New York: Chapman and Hall.

Kentish, S. and Feng, H. (2014). Applications of power ultrasound in food processing. Annual Reviews of Food Science and Technology, 5, 263-284. doi: 10.1146/annurev-food-030212-182537.

Koide, S., Takeda, J.I., Shi, J., Shono, H. and Griffiths, G. (2009). Disinfection efficacy of slightly acidic electrolyzed water on fresh cut cabbage. Food Control, 20, 294-297. doi: 10.1016/ j.foodcont.2008.05.019.

Kotula, A.W., Lusby, W.R., Crouse, J.D. and Vries, B. (1974). Beef carcass washing to reduce bacterial contamination. American Society of Animal Science, 39(4), 674-679. doi: 10.2134/jas1974.394674x.

Krieger, E.I.F. (2007). Evaluation of the water consumption, rationalization of the use and reuse of the liquid effluent of a pig slaughterhouse in the search of the socio-environmental sustainability, $\mathrm{p}$. 145. Brazil: Federal University of Rio Grande do Sul, PhD. Thesis.

Liao, L. B., Chen, W.M. and Xiao, X.M. (2006). The generation and inactivation mechanism of oxidationreduction potential of electrolyzed oxidizing water. Journal of Food Engineering, 78, 1326-1332. doi:10.1016/j.jfoodeng.2006.01.004

Liu, R., Xiangli, H., Jiaqi, S., Satoru, N., Eizo, T., Lite, L. and Haijie, L. (2013). The effect of electrolyzed water on decontamination, germination and gamaaminobutyric acid accumulation of brown rice. Food Control, 33(1), 1-5. doi: 10.1016/ j.foodcont.2013.02.008.

Mahmoud, B.S.M., Yamazaki, K., Miyashita, K., Kawai, Y., Shin, I.S. and Suzuki, T. (2006). Preservative effect of combined treatment with electrolyzed $\mathrm{NaCl}$ solutions and essential oil compounds on carp fillets during convectional air-drying. International Journal of Food Microbiology, 106, 331-337. doi: 10.1016/ j.ijfoodmicro.2005.09.010.

Marchioni, C., Riccardi, E., Spinelli, S., Dellunto, F., Grimaldi, P., Bedini, A., Giliberti, C., Giuliani, L. and Palomba, R. (2009). Structural changes induced in proteins by therapeutic ultrasounds. Ultrasonics, 49, 569-576. doi: 10.1016/j.ultras.2009.02.003.

Mane, B.G. and Dhanze, S.K. (2014). Tenderization of meat and meat products: a detailed review In Food composition and analysis: methods and strategies, $\mathrm{p}$. 93-115. USA: CRC Press

Mason, T. J. and Lorimer, J. P. (2002). Sonochemistry in environmental protection and remediation: the sonification of water In Applied sonochemistry: use of power ultrasound in chemistry and processing, $\mathrm{p}$. 137-138. USA: Wiley-vch,

Morild, R.K., Christiansen, P., Sorensen, A.H., Nonboe, U. and Aabo, S. (2011). Inactivation of pathogens on pork by steam-ultrasound treatment. Journal of Food Protection, 74, 769-775. doi: dx.doi.org/10.4315/0362-028X.JFP-10-338.

Northcutt, J., Smith, D., Ingram, K.D., Hinton, A. and Musgrove, M. (2007). Recovery of bacteria from broiler carcasses after spray washing with acidified electrolyzed water or sodium hypochlorite solutions. Poultry Science, 86, 2239-2244. doi: 10.1093/ ps/86.10.2239.

Pagan, R., Manas, P., Raso, J. and Condon, S. (1999). Bacterial resistance to ultrasonic waves under pressure at nonlethal (manosonication) and lethal (manothermosonication) temperatures. Applied and Environmental Microbiology, 65, 297-300.

Patil, R., Bhoir, P., Deshpande, P., Wattamwar, T., Shirude, M. and Chaskar, P. (2013). Relevance of sonochemistry or ultrasound (US) as a proficient means for the synthesis of fused heterocycles. Ultrasonic Sonochemistry, 8(6), 327-1336. doi: 10.1016/j.ultsonch.2013.04.002.

Raso, J., Pagan, R., Condon, S. and Sala, F.J. (1998). Influence of temperature and pressure on the lethality of ultrasound. Applied and Environmental Microbiology, 64, 465-471.

Rahman, S.M.E., Wang, J. and Oh, D. (2013). Synergistic effect of low concentration electrolyzed water and calcium lactate to ensure microbial safety, shelf life and sensory quality of fresh pork. Food Control, 30, 176-183. doi: 10.1016/ 
j.foodcont.2012.06.041

Rahman, S.M.E., Khan, I. and Oh, D. (2016). Electrolyzed water as a novel sanitizer in the food industry: current trends and future perspectives. Comprehensive Reviews in Food Science and Food Safety, 15(3), 1-20. doi: 10.1111/1541-4337.12200.

Santini, G.A. and Filho, H.M.S. (2003). Technological changes in agroindustrial chains: an analysis of the processing links of beef cattle, poultry and swine farming. Brazil: UNESP.

Sereia, V.J., Stal, E. and Camara, M.R. G. (2015). Determinants factors of innovation in meat agroindustrial. New Economy, 25(3), 647-672.

Shimamura, Y., Shinke, M., Hiraishi, M., Tsuchiya, Y. and Masuda, S. (2015). The application of alkaline and acidic electrolyzed water in the sterilization of chicken breasts and beef liver. Food Science and Nutrition, 4(3), 431-440. doi: 10.1002/fsn3.305

Shirahata, S., Kabayama, S., Nakana, M., Miura, T., Kusumoto, K., Gotoh, M. and Hayashi, H. (1997). Electrolyzed-reduced water scavenges active oxygen species and protects DND from oxidative damage. Biochemical and Biophysical Research Communications, 234, 269-274. doi: 10.1006/ bbrc.1997.6622.

Shiroodi, S.G., Ovissipoura, M., Ross, C.F. and Rasco, B.A. (2016). Efficacy of electrolyzed oxidizing water as a pretreatment method for reducing Listeria monocytogenes contamination in cold smoked Atlantic salmon. Food Control, 60, 401-407.doi: 10.1016/j.foodcont.2015.08.020

Shchukin, D. G., Skorb, E., Belova, V. and Mohwald, H. (2011). Ultrasonic cavitation at solid surfaces. Advanced Materials, 23, 1922-1934. doi: 10.1002/ adma.201004494

Sullivan, J.O., Murray, B., Flynn, C. and Norton, I. (2016). The effect of ultrasound treatment on the structural, physical and emulsifying properties of animal and vegetable proteins. Food Hydrocolloids, 53, 1-14. doi: 10.1016/j.foodhyd.2015.02.009.

Suslick K. S., Hammerton, D.A. and Cline, R.E. (1986). Sonochemical hot spot. Journal of the American Chemical Society, 108(18), 5641-5642.

Suslick, K. S. (1989). The chemical effect of ultrasound. Scientific American, 260(2), 80-86. doi: 10.1038/ scientificamerican0289-80.

Tozzeti, D.S., Santos, L.M., Maia, J.J.F., Negri, D. and Pereira, D.M. (2009). Disinfectants, efficiency and cost. Veterinary Medicine Electronic Journal, 7(12).
Turienzo, L. R., Cobos, A. and Diaz, O. (2012). Effects of edible coatings based on ultrasound-treated whey proteins in quality attributes of frozen Atlantic salmon (Salmosalar). Innovative Food Science and Emerging Technologies, 4, 92-98. doi: 10.1016/ j.ifset.2011.12.003.

Vieira, S.L. (1999). Current concepts of quality in chicken products: Effect of initial nutrition. International Symposium on Technology, Processing and Quality of Poultry, p. 60-68. Brazil: Embrapa

Xiong, G. Y., Zhang, L. and Wu, J. (2012). Influence of ultrasound and proteolytic enzyme inhibitors on muscle degradation, tenderness and cooking loss of hens during aging. Czech Journal Food Science, 30 (3), 195-205. doi: 10.1021/jf061576w.

Zacharia, A.I., Kamitani, Y. and Tiisekwa, A. Morita, K. and Iwasaki, K. (2010). In vitro inactivation of Escherichia coli, Staphylococcus aureus and Salmonella spp. using slightly acidic electrolyzed water. Journal of Bioscience and Bioengineering, 110, 308-313. doi: 10.1016/j.jbiosc.2010.03.012

Zhang, C., Lu, Z., Li, Y., Shang, Y., Zhang, G. and Cao, W. (2011). Reduction of Escherichia coli O157:H7 and Salmonella Enteritidis on mung bean seeds and sprouts by slightly acidic electrolyzed water. Food Control, 22, 792-796. doi:10.1016/ j.foodcont.2010.11.018

Zhou, Y., He, Q., Su, D. and Huang, H. (2015). Effects of ultra-high pressure tenderizing treatment on the quality characteristics of venison. Journal of Food Process Engineering, 39(2), 196-203. doi: 10.1111/ jfpe. 12214

Zoulias, E., Varkaraki, E., Lymberopoulos, N., Christodoulou, C.N. and Karagiorgis, G.N. (2013). A review on water electrolysis. Retrieved from Hydrogen Oman website: http://hydrogenoman.com/ docs/click\%20on\%20the\%20attached.pdf 